\title{
The Epidemiology of Norovirus 2014-2017
}

\author{
Brina Griffea-Hollis ${ }^{1}$, Deanna Melton-Riddle, ${ }^{2, *}$ \\ ${ }^{1}$ School of Health Sciences, Kaplan University, Davenport, IA, USA \\ ${ }^{2}$ Health Care Management, Parker University, Walnut Hill, TX, USA \\ *Corresponding author: brina.hollis@gmail.com
}

\begin{abstract}
The burden of disease can be detrimental to individuals, health systems and can be an overall burden on the public health system. While there have been efforts to educate the public on the prevention of the Norovirus, the emergence of outbreaks of Norovirus continue to increase across the United States. This purpose of this article is to present data on the outbreaks of Norovirus from years 2014-2017 and suggest additional options to help improve education of the general public in an effort to combat the disease.
\end{abstract}

Keywords: public health, epidemiology, norovirus, HuNoV

Cite This Article: Brina Griffea-Hollis, and Deanna Melton-Riddle, "The Epidemiology of Norovirus 2014-2017." American Journal of Public Health Research, vol. 6, no. 2 (2018): 40-43. doi: 10.12691/ajphr-6-2-3.

\section{Introduction}

Human norovirus (HuNoV) was discovered in the late 1960 s by a medical doctor, Albert Z. Kapikian, at an elementary school in the small town of Norwalk, Ohio. Initially known as the Norwalk virus, HuNoV is now referred to by various names, and this lack of standard nomenclature, together with the non-specific nature of the symptoms that it causes, have meant that cases of $\mathrm{HuNoV}$ have been under-reported. The infectious agent belongs to one of the four genera in the Caliciviridae family of viruses. The purpose of this paper is to review what is known about HuNoV and its genotypes and to present the results of a survey of laypersons regarding its transmission. This non-encapsulated, single-stranded RNA virus merits attention because it impacts over 250 million individuals annually, being responsible for more than $90 \%$ of viral gastroenteritis cases worldwide [1].

The current prevention protocol for HuNov includes proper hand-washing and washing and cooking of food products before consumption, but these steps cannot completely safeguard against infection. Moreover, despite enormous efforts to improve hygiene through education, hand-washing behavior remains inconsistent and, as the saying goes, one rotten apple spoils the barrel: an individual with unwashed hands can spread HuNoV rapidly and efficiently.

HuNov has been reported in a wide range environment, from schools, day care centers, and nursing homes to hotels and cruise ships. Thus, for example, some 800 students and staff at a school in St. Charles, Illinois, recently contracted the illness. There is at present no diagnostic tool for HuNov infection in an individual prior to the onset of symptoms. The virus can be contracted more than once by the same individual owing to the various strains that arise through mutations; moreover, it continues to be shed in the stool of infected individuals for up to two weeks after the cessation of symptoms [1]. The following discussion explores attitudes within the general population regarding the transmission of $\mathrm{HuNoV}$.

\subsection{Epidemiology and Public Health Burden}

Human norovirus is one of the leading causes of acute gastrointestinal illness in the United States, being responsible for over half of foodborne illnesses [2,3]. The three genogroups of $\mathrm{HuNoV}$ that cause illness among humans have been designated GI, GII, and GIV, among which there are more than 25 different genotypes. Additionally, $\mathrm{HuNoV}$ is, as indicated above, indiscriminate, with the potential to infect anyone at any place and at any time, though individuals with weak immune systems, such as children and the elderly, are at particular risk. According to a recent study by Kasrt and Wobus [4], GII is the genotype that most often infects children.

The virus spreads rapidly in close quarters, can survive on surfaces for more than a week, is resistant to many common killing agents, and shows persistence [1]. Common transmission routes include contaminated food and contact with an infected individual. Recent reports have indicated that vomitus may also transmit $\mathrm{HuNoV}$ and that cloth seating and other kinds of furniture may harbor the virus [5].

Recent literature has documented mortality and serious and long-term conditions caused by the virus [6]. It is responsible for more than 200,000 deaths per year, only about 800 of which occur in the United States [7,8,9], and for the hospitalization of more than 60,000 individuals, 400,000 emergency room visits, nearly two million outpatient visits, and some 20 million total illnesses annually [10]. Adding to this impact is the recent demonstration that $\mathrm{HuNoV}$ can undergo antigenic shift or variation that can produce new strains that further burden the healthcare system [11]. There are numerous reports of norovirus in the literature (See Table 1), in particular in connection with foodborne illness (See Table 2). 
Table 1. Reports of Norovirus

\begin{tabular}{|c|c|c|c|c|}
\hline Author & Title & $\begin{array}{c}\text { Publication } \\
\text { year }\end{array}$ & Population & Genogroup \& Genotype \\
\hline $\begin{array}{l}\text { Kumazaki, Makoto; } \\
\text { Usuku, Shuzo }\end{array}$ & $\begin{array}{l}\text { NOROVIRUS genotype distribution in outbreaks } \\
\text { of acute gastroenteritis among children and older } \\
\text { people: an 8-year study. }\end{array}$ & 2016 & $\begin{array}{l}\text { Nursery school \& } \\
\text { Nursing home }\end{array}$ & $\begin{array}{c}\text { GI: (GI.2, GI.3, GI.4, GI.6, } \\
\text { GI.5 and GI.7) } \\
\text { GII:(GII.2, GII.3, GII.4, GII.5, } \\
\text { GII.6, GII.7, GII.12, GII.13, } \\
\text { GII.14,GII.15 and GII.17) }\end{array}$ \\
\hline $\begin{array}{l}\text { He, Yaqing; Jin Miao; } \\
\text { Chen, Kena et. Al }\end{array}$ & $\begin{array}{c}\text { Gastroenteritis outbreaks Associated with the } \\
\text { Emergence of the New GII.4 Sydney Norovirus } \\
\text { Variant during the Epidemic of 2012/13 in } \\
\text { Shenzhen City, China }\end{array}$ & 2016 & $\begin{array}{l}\text { Long Term Care } \\
\text { home \& communal } \\
\text { factory }\end{array}$ & GII.4 \\
\hline $\begin{array}{l}\text { Wang, X., Yong, W., } \\
\text { Shi, L., et. al. }\end{array}$ & $\begin{array}{l}\text { An outbreak of multiple norovirus strains on a } \\
\text { cruise ship in China } 2014 .\end{array}$ & 2015 & Cruise Ship & $\begin{array}{l}\text { GI.1, GI.2, GI.3, GI.4, GI.8, } \\
\text { GI.9, GII.17 }\end{array}$ \\
\hline $\begin{array}{l}\text { Leshem, E., Barclay, } \\
\text { L., Wikswo, M., et. al. }\end{array}$ & $\begin{array}{l}\text { Genotype GI.6 Norovirus, United States, 2010- } \\
2012 .\end{array}$ & 2013 & $\begin{array}{l}\text { Multiple states \& } \\
\text { locations within } \\
\text { U.S. 2010-2012 } \\
\end{array}$ & GI.6 \\
\hline $\begin{array}{l}\text { Britton, C. L., Guzzle, } \\
\text { P. L., Hahn, C. G., \& } \\
\text { Carter, K. K. }\end{array}$ & $\begin{array}{l}\text { Norovirus outbreak at a wildland fire base camp } \\
\text { ignites investigation of restaurant inspection } \\
\text { policies. }\end{array}$ & 2014 & Restaurant & GI \& GII \\
\hline
\end{tabular}

Table 2. CDC Reports of Foodborne Norovirus

\begin{tabular}{|c|c|c|c|c|}
\hline Year & Outbreaks & Illnesses & Hospitalizations \\
\hline 2013 & 263 & 5057 & 33 & 65 \\
\hline 2014 & 288 & 5577 & 69 & 69 \\
\hline 2015 & 316 & 5767 & 1 & 6 \\
\hline
\end{tabular}

Table 3. CDC Confirmed Cases of Norovirus by State from September 1, 2016 to April 21, 2017

\begin{tabular}{|c|c|c|c|c|c|c|c|c|c|}
\hline State & $\begin{array}{c}\# \text { of } \\
\text { Outbreaks }\end{array}$ & State & $\begin{array}{c}\# \text { of } \\
\text { Outbreaks }\end{array}$ & State & $\begin{array}{c}\text { \# of } \\
\text { Outbreaks }\end{array}$ & State & $\begin{array}{c}\text { \# of } \\
\text { Outbreaks }\end{array}$ & State & $\begin{array}{c}\text { \# of } \\
\text { Outbreaks }\end{array}$ \\
\hline Alabama & 11 & Hawaii & 6 & Michigan & 18 & New Mexico & 2 & Texas & 2 \\
\hline Arizona & 3 & Idaho & 3 & Minnesota & 13 & New York & 6 & Utah & 2 \\
\hline Arkansas & 1 & Indiana & 19 & Mississippi & 4 & $\begin{array}{c}\text { North } \\
\text { Carolina } \\
\end{array}$ & 7 & Vermont & 2 \\
\hline California & 52 & Iowa & 13 & Missouri & 5 & Ohio & 31 & Virginia & 43 \\
\hline Colorado & 2 & Kansas & 16 & Montana & 4 & Oregon & 47 & Washington & 1 \\
\hline Connecticut & 3 & Louisiana & 8 & Nebraska & 5 & Pennsylvania & 7 & $\begin{array}{c}\text { West } \\
\text { Virginia } \\
\end{array}$ & 3 \\
\hline Florida & 7 & Maryland & 28 & Nevada & 1 & $\begin{array}{c}\text { South } \\
\text { Carolina }\end{array}$ & 11 & Wisconsin & 87 \\
\hline Georgia & 1 & Massachusets & 7 & $\begin{array}{c}\text { New } \\
\text { Hampshire }\end{array}$ & 5 & Tennessee & 10 & Wyoming & 7 \\
\hline
\end{tabular}

See Appendix A for breakdownby state

Current HuNOV Outbreaks: Surveillance and Reporting

During 2016 and 2017, HuNOV cases have continued to be reported in the news and by public health agencies. In 2016, universities, day care centers, cruise ships, primary schools, and nursing homes suffered outbreaks. Often, however, norovirus goes undetected because sick individuals mistake the illness as stomach influenza (flu). Table 3 outlines the number of confirmed cases of norovirus by state.

Diagnosis and Prognosis

Diagnosis of HuNoV involves detecting the antigen in the stool of the infected using a reverse transcriptase polymerase chain reaction assay (RT-PCR). RT-PCR can be difficult to perform, however, so, at least until recently, rapid, real-time tests for $\mathrm{HuNoV}$ in humans have not been available. While the duration of HuNov is usually only one to two days, the symptoms that present can be severe, and the duration can be longer for patients with a compromised or weakened immune system.

Problem:

Over the past several years, outbreaks of the norovirus have increased rapidly, and they continue to be on the rise, $[7,8,9]$. This unfavorable situation may be attributable to a lack of awareness and understanding regarding the origins and causes of HuNoV infection on the part of the general population.

\section{Materials and Methods}

This study used a survey research design to investigate the level of knowledge regarding the spread of norovirus among the general population of the United States. We also compare our findings with those from previously published studies of laypersons' knowledge of norovirus. Our hypothesis can be expressed simply as follows:

H1. There is a lack of awareness among the general population regarding $\mathrm{HuNoV}$ and how it spreads.

We collected data using a survey questionnaire based on one available on the Centers for Disease Control (CDC) webpage dedicated to norovirus; www.cdc.gov/norovirus/index.htm. The questions on the survey concern the transmission, prevention, and control of $\mathrm{HuNoV}$, particularly with respect to the handling of food. This survey has been used by Kosa et. al. [12] to investigate knowledge of HuNov among food service workers. The various questions were input into Question Pro software and the responses were tabulated. This anonymous study produced results in aggregate form. The randomized sample consisted of 45 laypersons living in 
the United States who responded to the survey $(\mathrm{N}=45)$. Demographic and geographical attributes did not determine participation in the survey. Descriptive statistics are used below to report the findings.

\section{Findings}

The research questions reflect our interest in laypersons' basic knowledge of $\mathrm{HuNoV}$ and its transmission. The survey responses provide new information regarding potential opportunities to educate the public about HuNoV. The following narrative describes the findings of the survey.

As mentioned, there is no vaccine against $\mathrm{HuNoV}$, but $22 . \%$ of the participants still believed that such a vaccine does exist. Likewise, while antibiotics have no effect on viruses [1], 20\% held that $\mathrm{HuNoV}$ infections can be treated using these drugs. On the other hand, the susceptibility of specific age groups to the disease was well known, with $89 \%$ of participants agreeing that children under 5 and adults over 65 are at particular risk. Then again, while $\mathrm{HuNoV}$ is one of the leading viral source of foodborne illness [1] and one of the four leading causes of fatal foodborne illnesses [7,8,9], $82 \%$ of the participants in this study expressed the opinion that bacteria are responsible for more foodborne illnesses than viruses. Regarding the year-round persistence of HuNov in the environment but greater prevalence in the winter months, $60 \%$ of the participants were aware that $\mathrm{HuNoV}$ infection is more common at this time of the year.

Infection with HuNoV confers no immunity, as $84 \%$ of the participants in this study were aware. Responses regarding transmission of the virus-which again can be through food, fecal matter, vomitus, or contaminated hands-were as follows. Most respondents, 77\%, were of the opinion that those infected with HuNoV should not prepare food, even after washing their hands, and an even larger portion, 88.\%, were aware that infection can persist for as much as three days after all signs and symptoms disappear. In fact, in many cases, viruses and bacteria can be spread by a single infected person. Ready-to-eat meals are one of the ways in which HuNov frequently spreads $[8,12]$. Returning to the survey, $80 \%$ of respondents correctly identified person-to-person contact as the most common form of transmission [1]. As mentioned, HuNoV can survive on porous materials and upholstery-the CDC has developed protocols for cleaning such surfaces of the virus-as $71 \%$ of participants were aware. Regarding the common association of $\mathrm{HuNoV}$ with cruise ships, while there have been 31 outbreaks in this context in the period from 2014-2017 [13], in fact the vast majority of outbreaks occur in other contexts. In responding to the survey, though, $55 \%$ of respondents identified cruise ships as the most common location for outbreaks.

In terms of hygenic measures, $53 \%$ of participants were of the opinion that hand sanitizes are not as effective as hand washing against $\mathrm{HuNoV}$. Further, regarding antimicrobial soaps-the use of which has increased in the past decade because many consumers are under the impression that they help to keep the body free of diseasecausing organisms-57\% of the participants in this study considered them effective, though in fact, according to the
Food and Drug Administration [14], such soaps have not been shown to prevent any bacterial or viral illness. Similarly, while $80 \%$ and $88 \%$ of respondents, respectively, held that quaternary ammonium compounds and chlorine bleach at 100 parts per million are effective sanitary measures for combating transmission of $\mathrm{HuNoV}$, the CDC [9] has reported that the former are ineffective and that bleach is ineffective below 1000 parts per million.

Food is one of five most commong vectors for transmitting HuNov; clams, mussels, and oysters in particular are often contaminated by tainted water. Further, because $\mathrm{HuNoV}$ can withstand heat of up to $140^{\circ} \mathrm{F}$, steaming shellfish for 3-5 minutes is not sufficient protection against it, though only $35 \%$ of participants were mistaken in this respect. Salads, deli sandwiches, and other foods that do not require heating before consumption also carry an especially high risk of $\mathrm{HuNoV}$ contamination, and in the survey, $62 \%$ participants identified the risk associated with ready-to-eat foods. Moreover, $91 \%$ of respondents were of the correct opinion that any type of food or beverage can become contaminated with HuNoV. A study by Todd et. al., [15] reported that $60 \%$ of HuNov infection can be traced to direct food handling by an infected person. Such carries can contaminate fresh produce, as can the equipment used to prepare it; in the survey, $37 \%$ of participants expressed the belief that fresh produce is always contaminated with $\mathrm{HuNoV}$ by infected workers. Moreover, while infected service workers should not handle any food or utensils, $68 \%$ of participants answered that infected food service workers did not pose a risk when handling wrapped food and utensils.

In addition to the above questions, participants were also asked about their awareness of the most common sources of food borne disease in the United States, and only $24 \%$ answered in the affirmative, while $33 \%$ reported that they were not aware of the most common human behaviors that contribute to foodborne illness.

\section{Conclusions and Recommendations}

It was concluded that overall, participants of this study had a foundational level of knowledge related to $\mathrm{HuNoV}$ origins, transmission, prevention methods and the impact of proper food handling. The most significant deficiencies in knowledge base could be seen in 4 particular areas, one being that of food handling, with a majority of the participants surveyed $(68 \%)$ do believe that food handlers who have been infected with HuNoV can come in contact with wrapped food and soiled utensils. While it is worth mentioning that most of the participants were aware of the populations who were most affected by HuNoV outbreaks (elderly and children) at $88.89 \%$, a large portion were under the impression that the virus could be treated with a vaccine $(22 \%)$. Along the same lines, $20 \%$ of the survey participants believe that $\mathrm{HuNoV}$ can be treated with antibiotics. The final area which showed significant findings in lack of knowledge focused on handwashing and the use of antimicrobial soap, which showed that $57 \%$ of the participants believe that it is effective in fighting against HuNoV. Based upon these findings, the researchers believe that increased resources and initiatives 
to educate the population on the Norovirus will help prevention efforts, and should occur at the state and local levels. Especially in states such as North Carolina and Illinois, where significant outbreaks of the virus occurred as identified through the data findings, the availability of health forums and educational materials that provide in depth information regarding the origin of $\mathrm{HuNoV}$, with focused segments that highlight each of the four survey areas where knowledge deficiencies were found would be of great benefit. In addition, the development of a series of webinars and public service announcements sponsored on national platforms would increase awareness of $\mathrm{HuNoV}$. Efforts to promote awareness and prevention should also be implemented by consistent health education via health care providers, as well as health education specialists that educate the general public and communities at large would prove to advance the knowledge and understanding of how the Norovirus is spread, and steps that can be taken to safeguard against infection. It is also recommended that a specialized focus on food sanitation services be included in education efforts, by way of training. The training would serve best offered as a separate component that is required for all individuals who work in the areas of hospitality, hotel management and restaurant services and should occur on an annual basis.

\section{References}

[1] Centers for Disease Control. "Norovirus Illness: Key Facts”. 2015. [Online]. Available:

https://www.cdc.gov/norovirus/downloads/keyfacts.pdf. [Accessed Aug. 3, 2017].

[2] Barry Rockx, Matty de Wit, Harry Vennema, Jan Vinjé, Erwin de Bruin, Yvonne van Duynhoven, Marion Koopmans (2002). Natural History of Human Calicivirus Infection: A Prospective Cohort Study, Clinical Infectious Diseases, Volume 35, Issue 3, 1 Pages 246-253,

[3] Kapikian, A. Z., \& Wyatt, R. G. (1977). Viral agents associated with acute gastroenteritis in humans. American Journal of Clinical Nutrition, 30(11), 1857.

[4] Karst, S.M., and Wobus, C. E, "A Working Model of How Noroviruses Infect the Intestine", Plos Pathogens, 11(2). 1-7.
[5] Escudero, B.I., Rawsthorne, H., Gensel, C., \& Jaykus, L.A, "Persistence and transferability of noroviruses on and between common surfaces and foods", Journal Of Food Protection, 75(5). 927-935. 2012.

[6] Joukje Siebenga, J., Vennema, H., Zheng, D.-P., Vinjé, J., Lee, B.E., Pang, X.-L., and Ho, E.C.M, "Norovirus Illness Is a Global Problem: Emergence and Spread of Norovirus GII.4 Variants, 2001-2007", Journal of Infectious Disease, 2009 (5). 802-812.

[7] Centers for Disease Control. "Burden of Foodborne Illness: Questions and Answers". 2016a. [Online]. Available: https://www.cdc.gov/foodborneburden/questions-andanswers.html. [Accessed Retrieved Aug. 4, 2017].

[8] Centers for Disease Control. "Nororvirus - Transmission". 2016b. [Online]. Available: https://www.cdc.gov/norovirus/about/transmission.html. [Accessed Aug. 9, 2017].

[9] Centers for Disease Control. "Preventing Norovirus Infection". 2016c. [Online]. Available:

https://www.cdc.gov/norovirus/preventing-infection.html. [Accessed Aug. 11, 2017].

[10] Hall, A.J., Lopman, B.A., Payne, D.C., Patel, M.M., Gastañaduy, P.A., Vinjé, J., et al. "Norovirus disease in the United States", Emerging Infectious Diseases. August 2013.

[11] Lindesmith LC, Donaldson EF, Baric RS. (2011). Norovirus GII.4 strain antigenic variation. Journal of Virology. $2011 \mathrm{Jan}$; 85(1): 231-42.

[12] Kosa, K.M., Cates, S.C., Hall, A. J., Brophy, J.E., and Fraser, A, "Gaps in food safety professionals' knowledge about noroviruses", Journal of Food Protection, 77. 1336e-1341. 2014.

[13] Centers for Disease Control. "Vessel Sanitation Program: Outbreak Updates for International Cruise Ships”. 2017. [Online]. Available: http://www.cdc.gov/nceh/vsp/surv/gilist.htm\#2014. [Accessed Jan. 29, 2017].

[14] Food and Drug Administration. "Antibacterial Soap? You Can Skip It-Use Plain Soap and Water". 2017. [Online]. Available: https://www.fda.gov/ForConsumers/ConsumerUpdates/ucm37839 3.htm. [Accessed Aug. 11, 2017].

[15] Todd, E.C.D., Greig, J.D., Bartleson, C.A., Michaels, B.S, "Outbreaks where food workers have been implicated in the spread of foodborne disease. Part 3. Factors contributing to outbreaks and description of outbreak categories", Journal of Food Protection 70. 2199-2217. 2007.

[16] Britton, C.L., Guzzle, P.L., Hahn, C.G., and Carter, K.K, "Norovirus outbreak at a wildland fire base camp ignites investigation of restaurant inspection policies", Journal Of Environmental Health. 77 (1). 8-14. 2014.

[17] Leshem, E., Barclay, L., Wikswo, M., Vega, E., Gregoricus, N., Parashar, U. D., and ... Hall, A. J, "Genotype GI.6 norovirus, United States, 2010-2012", Emerging Infectious Diseases, 19(8). 1317-1320. 